\title{
Erratum to: Comparison of muscle ultrastructure in myasthenia gravis with anti-MuSK and anti-AChR antibodies
}

Giovanna Cenacchi - Valentina Papa •

Marina Fanin · Elena Pegoraro · Corrado Angelini

Published online: 11 January 2011

(C) Springer-Verlag 2011

Erratum to: J Neurol

DOI 10.1007/s00415-010-5823-x

Unfortunately, the list of authors was printed with errors.

The correct list is given here.

The online version of the original article can be found under doi:10.1007/s00415-010-5823-x.

G. Cenacchi $(\bowtie) \cdot$ V. Papa

Clinical Department of Radiological and Histopathological

Sciences, "Alma Mater Studiorum" University of Bologna,

Via Massarenti, 9, 40137 Bologna, Italy

e-mail: giovanna.cenacchi@unibo.it

M. Fanin · E. Pegoraro · C. Angelini

Department of Neurosciences, University of Padua, Padua, Italy 